\title{
Extraction, Phytochemical Screening, Isolation and Identification of Bioactive Compounds from Extract of the plant Euphorbia Thymifolia Linn
}

\author{
Rashmi Shrivastava ${ }^{1 *}$, Jyotsana Mishra ${ }^{2}$ \\ 1*Rabindranath Tagore University, Chiklod Rd, Mendua, Bhopal, Madhya Pradesh 464551 \\ 2Department of Chemistry, Scope College of Engineering, Hoshangabad Rd, Misrod, Bhopal, Madhya Pradesh 462026
}

\begin{abstract}
Medicinal plants play an important role in the development of potent therapeutic agents. Plant based drugs provide outstanding contribution to modern therapeutics as a source of many valuable secondary metabolites which serves as plant defense mechanisms against predator such as microorganism, insects and herbivores which have been proved to be potentially active compounds. Euphorbia Thymifolia Linn (E. Thymifolia) is commonly known as 'duddi' or in Sanskrit means Laghu didhika or Raktavindaka. It belongs to the family Euphorbiceae. This plant is bitter, acrid, sweet and used as thermogenic, laxative and diuretic. This plant is widely used in the ayurveda to cure many diseases like vitiated condition of constipation, helminthiasis and ringworm skin diseases and leprosy. The aim of the present study is to examine E.Thymifolia Linn whole plant for phytochemical profile, Isolation and Identification of bioactive compounds. Qualitative analysis of various phytochemical constituents was determined by the well-known test protocol available in the literature. Isolation and characterization of bioactive compound from methanolic extract of E. Thymifolia has been conducted. The bioactive compound from methanolic extracts was isolated by several processes, such as TLC, column chromatography and preparative TLC. The isolated bioactive compound is identified by UV-Vis spectrophotometer, FT-IR, ${ }^{1} \mathrm{H}, 13 \mathrm{C}$-NMR and Mass. The obtained compound is continued to the preparative TLC using chloroform: methanol (50:50, v/v) as eluent. The UV-Vis spectrum showed one peaks of maximum absorbance at $312.8 \mathrm{~nm}$. Then, the FT-IR spectrum showed several peaks that confirmed the presence of functional group of derivative of compound, i.e. $669.05,928.58,1070.85,1215.51$ and $1710.07 \mathrm{~cm}-1 .{ }^{1} \mathrm{H}$ and 13C-NMR spectrum confirmed the bioactive compound present in plant. Phytochemical analysis revealed the presence of alkaloids, glycosides, phenols, flavonoids, tannins. The findings of the present study will be helpful to phytochemists, pharmacologists and pharmaceutical industries.
\end{abstract}

Keywords: Euphorbia Thymifolia, Qualitative phytochemical, Isolation, Bioactive compounds

Article Info: Received 18 March 2019; Review Completed 2April 2019; Accepted 24 April 2019; Available online 15 May 2019

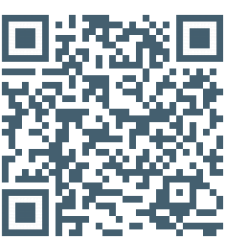

Cite this article as:

Shrivastava R, Mishra J, Extraction, Phytochemical Screening, Isolation and Identification of Bioactive Compounds from Extract of the plant Euphorbia Thymifolia Linn, Journal of Drug Delivery and Therapeutics. 2019; 9(3):107-113 http://dx.doi.org/10.22270/jddt.v9i3.2608

Rashmi Shrivastava, Department of Chemistry, Rabindranath Tagore University, Chiklod Rd, Mendua, Bhopal, Madhya Pradesh 464551

\section{INTRODUCTION}

Ayurveda stresses on the use of vegetable drugs. Plants are being used as medicine since ancient Times ${ }^{1,2}$. A numbers of bioactive compounds in medicinal plants, such as alkaloids, tannins, flavonoids, sterols, triterpenes, etc., are noted to play major role in physiology and management of diseases ${ }^{3}$ Flavonoids constitute one of the most exclusive classes of compounds in medicinal plants 4 . The foremost important task in this paradigm is the screening of flavonoids in plants. Phenolic compound are the most widely distributed secondary metabolites, ubiquitously present in the plant kingdom, even if the type of compound present varies according to the phylum under consideration. Phenolic are uncommon in varies bacteris, fungi and algae. Bryophytes are regular producers of polyphenols including flavonoids, but it is in the vascular plants that the full range of polyphenol is found 5 . Phenolic substances or polyphenols contain numerous varieties of compounds: simple flavonoids, phenolic acids, complex flavonoid and colored anthocyanins. These phenolic compounds are usually related to defense responses in the plant. However, phenolic metabolites play an important part in other processes, for instance incorporating attractive substance to accelerate pollination, coloring for camouflage and defense against herbivores, as well as antibacterial and atifungal activities ${ }^{6}$. Chromatographic studies of these compounds serves to be a very useful and reliable source in the process of bioactive compounds screening in plants ${ }^{7}$. According to the ethnobotanical information, it has been reported that the plant E. Thymifolia (family- Euphorbiaceae) is a medicinal herb used traditionally in dysentery, bleeding piles, gonorrhoea, dysmenorrhoea, amenorrhoea, helminthiasis, ringworm, chronic cough, asthma, bronchitis, cardiac debility, greying of hairs, skin diseases etc ${ }^{8}, 9$. E. Thymifolia have numerous pharmacological activities including antibacterial $^{10,} 11$, antifungal ${ }^{12}$, antimicrobial ${ }^{13}$, antiinflammatory ${ }^{14,15}$, antiviral 16 , antispasmodic, bronchodilator, 
antibronchial, asthmatic 17-19, hypoglycaemic $20-22$, anticancer ${ }^{23,24}$ and antioxidant 25 . A number of chemical constituents are present in E. Thymifolia whole herb and its different parts. According to the literature, the whole plant contains epitaraxerol, n-hexacosanol, euphorbol, 24methylene cycloartenol, 12-deoxy-4P-hydroxyphorbol-13dodecanoate-20-acetate, 12-deoxy-4P-hydroxyphorbol-13phenylacetate-20-acetate, 12-deoxyphorbol-13,20-diacetate, quercetin-3P-galactoside, 12-deoxyphorbol-13,20-diacetate, 12-deoxy-4Phydroxyphorbol-13-dodecanoate-20-acetate, nhexacosanol, esters, n-alkanes and sterols 26,27 . Roots contain taraxerol and triucallol. Leaves and stems consist of 4trihydroxy flavone-7- glycoside ${ }^{26}$. Leaves contain ellagitannin dimers, euphorbins $\mathrm{G}$ and $\mathrm{H}$ with 12 known polyphenols ${ }^{27-32}$. Therefore, the aim of this research is extraction, isolation, phytochemical screening and identification of bioactive compounds from methanolic extract of E. Thymifolia whole herb through several processes, such as thin layer chromatography, column chromatography and preparative TLC. To identify the structure of bioactive compound, several analyses has been conducted such as UV-Vis, FT-IR, ${ }^{1} \mathrm{H}, 13 \mathrm{C}-\mathrm{NMR}$ and mass.

\section{MATERIAL AND METHOD}

\section{Plant material}

The whole plant material of $E$. Thymifolia was collected from the Betwa riverine zone of Vidisha during rainy seasons of the year 2014 and washed thoroughly with distilled water. It was identified and authenticated by Taxonomist Dr. Sunil Dubey, Department of Botany, St. Mary P. G. College, Vidisha (M.P.). A voucher specimen was procured which was deposited in Department of Botany and Microbiology, St. Mary's P. G. College, Vidisha (M. P.) for future reference and the specimen voucher no. of $E$. Thymifolia is 104105.

\section{Chemical reagents}

All the chemicals used in this study were obtained from HiMedia Laboratories Pvt. Ltd. (Mumbai, India), Sigma Aldrich Chemical Co. (Milwaukee, WI, USA), SD Fine-Chem Chem. Ltd. (Mumbai, India) and SRL Pvt. Ltd. (Mumbai, India).All the chemicals used in this study were of analytical grade.

\section{Extraction Procedure}

\section{Defatting of plant material}

Plant material of E. Thymifolia was shade dried at room temperature. The shade dried plant material was coarsely powdered and subjected to extraction with n-Hexane using soxhlation method. The extraction was continued till the defatting of the material had taken place.

\section{Extraction}

$100 \mathrm{gm}$ of dried plant material were exhaustively extracted with different solvent in increasing order of polarity i.e. nHexane, petroleum ether, benzene, acetone, methanol and distilled water using Soxhlet apparatus for 4 days. The extract was evaporated above their boiling points. Finally the percentage yields were calculated of the dried extracts. Dried extract was collected in an air tight container and stored at $4^{\circ} \mathrm{C}$ for further analysis ${ }^{33-36}$.

\section{Qualitative analysis of phytochemicals}

The methanolic extracts prepared for the study were subjected to preliminary phytochemical screening by using different reagents for identifying the presence or absence of various phytoconstituents viz., carbohydrates, proteins, alkaloids, tannins, steroid, flavonoids and terpenoids in methanolic extracts of E. Thymifolia. The above phytoconstituents were tested as per the standard method ${ }^{37}$.

Fractionation of the extract by thin layer and column chromatography

\section{Thin layer chromatography}

The presence of different phytoconstituents in the methanolic extract of plant E. Thymifolia was established by TLC on silica coated alumina plates G' 60 F254 plate of 0.2 $\mathrm{mm}$ thickness by using different solvent systems as mobile phase. The selective solvent system used for the phytoconstituents detection was Chloroform (50): Methanol (50). A spotting capillary was used to add the extract to the plate. To spot the plate, simply touched the end of the capillary tube to the coated side of the plate and placed the TLC plate in the development chamber. The bottle was filled with a small amount of the mobile phase of solvent system and capped with a cork till complete development. After the complete development of spots on TLC plates, UV Chamber under the wavelength $254 \mathrm{~nm}$ of UV light was used to visualize the spots and the spots color were noticed. Besides this, Iodine chamber and visible light was also used to visualize the spots. RF (retention factor) values of the fractions were measured by applying formula of Brimley and Barrett ${ }^{38}$ as:

\section{Distance travelled by the solvent \\ $R_{f}=--$ Distance travelled by the solute}

\section{Column chromatography}

In the present study, silica gel was used as a stationary phase which was poured in to the column then filled chloroform solvent as mobile phase and was run two three times for maintaining its flow by removing air bubbles entered during packaging of silica. Then loaded sample on the top of the column and filled the column with appropriate solvent systems. The selective solvent system used for phytoconstituents detection was Chloroform: Methanol (50:50). Then, obtained purified fractions were separated on basis of their color characterization and were kept in separate vials for further analysis.

\section{Isolation and structural elucidation of the compound}

The biologically active purified fractions of the extract were sent to PBRL (Pinnacle Biomedical Research Laboratory), Bhopal for spectral analysis (UV) and to the SAIF CDRI, Lucknow for spectral analysis (IR, HNMR, CNMR and Mass) and spectral graphs were obtained. Which were interpreted with the literature available in books of spectroscopic analysis 39,40 .

\section{RESULTS AND DISCUSSION}

The crude extracts so obtained after the maceration process, extracts was further concentrated on water bath for evaporate the solvents completely to obtain the actual yield of extraction.

Table 1: \% Yield of plant material

\begin{tabular}{|c|c|c|}
\hline S. No. & Solvents & Euphorbia Thymifolia \\
\hline 1 & N- hexane & $3.65 \%$ \\
\hline 2. & Pet. Ether & $1.56 \%$ \\
\hline 3. & Benzene & $2.96 \%$ \\
\hline 4. & Methanol & $7.34 \%$ \\
\hline 5. & Aqueous & $4.38 \%$ \\
\hline 6. & Acetone & $3.83 \%$ \\
\hline
\end{tabular}


To obtain the percentage yield of extraction is very important phenomenon in phytochemical extraction to evaluate the standard extraction efficiency for a particular plant, different parts of same plant or different solvents used. The yield of extracts obtained from sample using chloroform, ethyl acetate, methanol and water as solvents are depicted in the Table 1.
A small portion of the dried extracts were subjected to the phytochemical test using standard methods to test for alkaloids, glycosides, tannins, saponins, flavonoids and steroids separately for extracts of all samples. The outcomes of the results are discussed separately in the table 2 .

Table 2: Preliminary phytochemical screening of Euphorbia Thymifolia (Linn.) extracts.

\begin{tabular}{|c|c|c|c|}
\hline S. No. & Tests & Phytochemicals & Results \\
\hline 1 & $\begin{array}{l}\text { - Mayer's test } \\
\text { - Wagner's test } \\
\text { - Dragendorff's test } \\
\text { - Hager's test }\end{array}$ & Alkaloids & + \\
\hline 2 & $\begin{array}{l}\text { - Molisch's test } \\
\text { - Benedict's test } \\
\text { - Fehling's test }\end{array}$ & Carbohydrates & + \\
\hline 3 & $\begin{array}{l}\text { - Modified Borntrager's test } \\
\text { - Legal's test }\end{array}$ & Glycosides & + \\
\hline 4 & - Froth/Foam test & Saponins & - \\
\hline 5 & $\begin{array}{l}\text { - Salkowski's test } \\
\text { - Libermann-Burchard test }\end{array}$ & Steroids & + \\
\hline 6 & Gelatin test & Tannins & + \\
\hline 7 & $\begin{array}{l}\text { Alkaline Reagent test } \\
\text { - Lead acetate test }\end{array}$ & Flavonoids & + \\
\hline 8 & $\begin{array}{l}\text { - Xanthoproteic test } \\
\text { - Ninhydrin test }\end{array}$ & $\begin{array}{l}\text { Proteins } \\
\text { and amino acids }\end{array}$ & - \\
\hline 9 & Test for Triterpenes & Triterpenes & + \\
\hline
\end{tabular}

In the present study, thin layer chromatography of $E$. Thymifolia whole plant crude methanolic extract was done and three spots of solutes were seen on the plate between the distance travelled by the solvent system $(7.3 \mathrm{~cm})$. These fractions of solutes were observed at $2.5 \mathrm{~cm}, 5 \mathrm{~cm}$ and $6.3 \mathrm{~cm}$ distances, respectively Finally, RF (retention factor) values of the fractions were measured and given in table 3 .

Table 3 Thin layer chromatography of Euphorbia Thymifolia plant extract

\begin{tabular}{|c|c|c|c|c|c|c|}
\hline \multirow{2}{*}{$\begin{array}{l}\text { Plant Extract } \\
\text { Of Euphorbia } \\
\text { thymifolia }\end{array}$} & \multirow{2}{*}{$\begin{array}{c}\text { Solvent System } \\
\text { Used }\end{array}$} & \multirow{2}{*}{$\begin{array}{l}\text { No. of } \\
\text { spots }\end{array}$} & \multirow[t]{2}{*}{ RF Value } & \multicolumn{3}{|c|}{ Color characterization } \\
\hline & & & & Visual light & UV-light & Iodine chamber \\
\hline Methanol & $\begin{array}{l}\text { Chloroform (50): } \\
\text { Methanol (50) }\end{array}$ & $\begin{array}{l}\text { ET-1 } \\
\text { ET-2 } \\
\text { ET-3 }\end{array}$ & $\begin{array}{l}0.34 \\
0.68 \\
0.86 \\
\end{array}$ & $\begin{array}{l}\text { Light yellow } \\
\text { Yellow } \\
\text { Brownish green }\end{array}$ & $\begin{array}{l}\text { Bluish yellow } \\
\text { Dark yellow } \\
\text { Bluish green }\end{array}$ & $\begin{array}{l}\text { Dark Yellow } \\
\text { Dark brown } \\
\text { Brownish green }\end{array}$ \\
\hline
\end{tabular}

After the confirmation of solvent system applied in thin layer chromatography and obtained fractions of the extracts, the huge amount of extract was uploaded in column with the same solvent system after running column of silica gel with chloroform: methanol (50:50) solvent to separate the huge amount of the fractions of the extracts to use it for experimental bioassay. Four fractions of dark green, light green, pale yellow and red were obtained which were further used for experimental bio-assay and spectral analysis was given in table 4.

Table 4 Column chromatography of Euphorbia Thymifolia plant extract

\begin{tabular}{|c|c|c|c|}
\hline Whole plant extract & Solvent system used & Fractions obtained & Color characterization \\
\hline Euphorbia & Chloroform:Methanol & ET-1 & Dark green \\
thymifolia & $(50: 50)$ & ET-2 & Light green \\
& & ET-3 & Pale Yellow \\
& & ET-4 & Red \\
\hline
\end{tabular}

In the present study, biologically active purified fraction (ET2) of the E. Thymifolia whole plants methanolic extracts was analysed for the detection and confirmation of the bioactive compound present in the fraction. Sample of the purified fraction (ET-2) of E. Thymifolia was measured by using systronics double beam UV-VISIBLE Spectrophotometer Model 2202. Peaks as shown in fig. 1. Maximum absorbance of the extract 1.71 was reported at $\lambda \max 312.8 \mathrm{~nm}$ and minimum absorbance 0.511 was reported at $\lambda_{\max } 274.4 \mathrm{~nm}$ wavelength (in 95\% ETOH). The structured secondary band 
which appeared as broad band at $312.8 \mathrm{~nm}$ along with 1.71absorbance confirms the presence of cyclohexane like compound. Another broad band appeared at $\lambda_{\max } 274.4 \mathrm{~nm}$ along with 0.511 absorbance confirms the presence of cyclopentane like compound in the purified fractions.

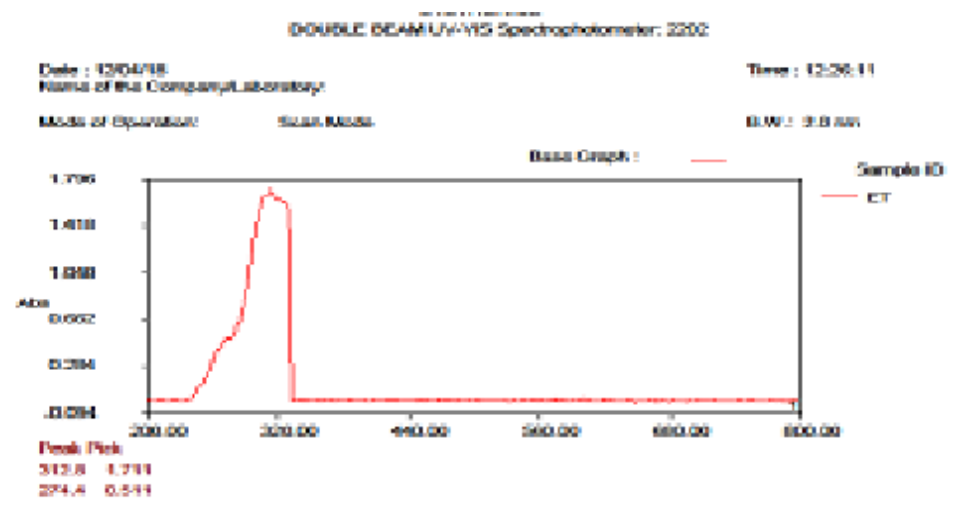

Figure 1: UV spectra of purified fraction (ET-2).

Sample ET-2 of E. Thymifolia was uploaded in Perkin Elmer Spectrum (Version 10.03.06) at SAIF, CDRI, Lucknow, (UP) by administrator to get IR spectra of the compound. Total 13 peaks were reported in the sample (ET-2) of E. Thymifolia MEOH fraction as shown in fig 2 which described that in finger print region $\left(<1500 \mathrm{~cm}^{-1}\right) 7$ peaks were observed. The smallest peak at $669.05 \mathrm{~cm}^{-1}$ belongs to the stretching vibration due to the presence of $\mathrm{O}-\mathrm{H}$ group. Another peak at $757.75 \mathrm{~cm}^{-1}$ confirmed the presence of aromatic ring compound isomer especially on its ortho position in aromatic ring $\left(770-735 \mathrm{~cm}^{-1}\right)$. The peak at $928.58 \mathrm{~cm}^{-1}$ showed Carbon Hydrogen banding vibration. The peak at $1070.85 \mathrm{~cm}^{-1}$ explains the strong intensity of C-O stretching. The peak at $1215.51 \mathrm{~cm}^{-1}$ reports medium intensity of $-\mathrm{C}-\mathrm{N}$.
A peak at $1384.12 \mathrm{~cm}^{-1}$ explains carbon hydrogen banding vibration $\mathrm{CH}_{3}$. One more peak at $1640.96 \mathrm{~cm}^{-1}$ indicates for Aromatic ring compound. Besides this, a peak at $1710.07 \mathrm{~cm}^{-1}$ explains strong intensity of double bond between Carbon and Oxygen $(\mathrm{C}=0)$. Moreover, a peak at $2399.74 \mathrm{~cm}^{-1}$ describes strong and very broad intensity of carboxylic acid. A peak at $2855.13 \mathrm{~cm}^{-1}$ also confirms the presence of cyclopentane and hexane like compound that is probably $\lambda$ Lactone. A small blunt peak at $2927.9 \mathrm{~cm}^{-1}$ shows strong Carbon-Hydrogen stretching vibration $(\mathrm{C}-\mathrm{C}-\mathrm{H})$, a peak at $3019.12 \mathrm{~cm}^{-1}$ depicts $\mathrm{O}-\mathrm{H}$ group stretching and finally a last peak at $3408.99 \mathrm{~cm}^{-1}$ describes strong and broad intensity of OH-group.

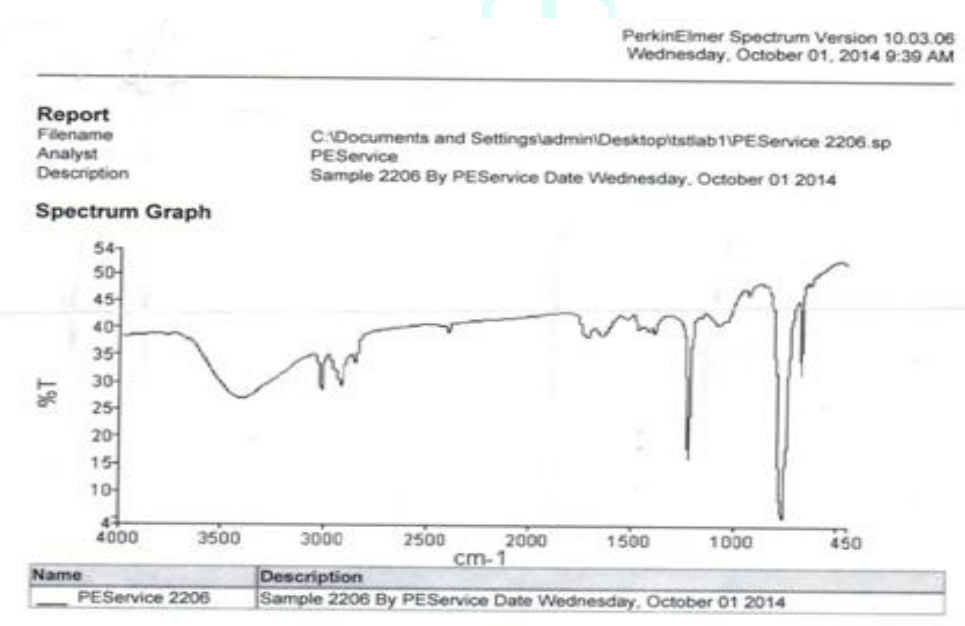

Figure 2: FT-IR Sspectra of purified fraction (ET-2)

The ${ }^{1}$ HNMR (Agilent, $\mathrm{CDCL}_{3}, 300 \mathrm{MHz}$ ) peaks observed at different concentration (ppm) describes the position of hydrogen in the compounds. Three small peaks were reported between $\delta 0.754$ to 0.787 ranges signify for $3 \mathrm{H}(\mathrm{s})$ and eight medium peaks were reported between $\delta 0.803$ to $\delta 0.898$ ranges signify for $3 \mathrm{H}(\mathrm{s})$. Besides this, five peaks of small size were seen between $\delta 0.920$ to $\delta 0.976(2 \mathrm{H}, \mathrm{m})$, and twenty seven peaks between $\delta 1.001$ to $\delta 1.730$ were reported out of these, $\delta 1.29(16 \mathrm{H}, \mathrm{m}), \delta 1.30(2 \mathrm{H}, \mathrm{s}), \delta 1.50$ $(3 \mathrm{H}, \mathrm{s}), \delta 1.62(2 \mathrm{H}, \mathrm{m})$. Moreover, eight peaks were reported between the ranges of $\delta 2.020$ to $\delta 2.806$. Out of these peaks, $\delta 2.03(2 \mathrm{H}, \mathrm{m}), \delta 2.05(2 \mathrm{H}, \mathrm{m})$, two peaks were seen of $\delta 5.352$ $(1 \mathrm{H}, \mathrm{m}), \delta 5.362(1 \mathrm{H}, \mathrm{m})$ and finally, one peak of $\delta 7.265$ was seen indicates for $(2 \mathrm{H}, \mathrm{d}, \mathrm{J}=0.75 \mathrm{~Hz})$ as shown in fig 3 which confirms the presence of sesquiterpene lactones in the purified fraction. The ${ }^{13} \mathrm{CNMR}$ (Agilent, 300MHz) peaks observed in the fig 4 at various concentration depicted the position of carbon and hybridization in the compound. First peak was of $\delta 12.17\left(\mathrm{q}, \mathrm{sp}^{3}, \mathrm{CO}-\mathrm{CH}_{3}\right)$, two peaks of $\delta 14.32$ and $\delta 14.47\left(\mathrm{t}, \mathrm{sp}^{2}\right.$-sp, $\left.\mathrm{O}-\mathrm{CH}_{3}\right)$, two peaks of $\delta 16.16$ and $\delta 16.30(\mathrm{~d}$, sp, $\mathrm{O}-\mathrm{CH}_{3}$ ), two peaks of $\delta 18.19$ and $\delta 18.50\left(\mathrm{t}, \mathrm{C}-3, \mathrm{sp}^{2}, 2 \mathrm{H}\right.$,$\mathrm{CH}_{2}$ ), three peaks of $\delta 19.23,19.51$ and $19.94\left(\mathrm{t}, \mathrm{sp}^{2}, \mathrm{C}-3,2 \mathrm{H}\right.$,$\mathrm{CH}_{2}$ ), two peaks of $\delta 20.01$ and $\delta 20.74\left(\mathrm{t}, \mathrm{sp}^{2}, \mathrm{C}-10,2 \mathrm{H},-\mathrm{CH}_{2}\right)$, one peak of $\delta 21.27\left(\mathrm{t}, \mathrm{sp}^{2}, \mathrm{C}-3, \mathrm{C}-5,2 \mathrm{H},-\mathrm{CH}_{2}\right)$, three peaks of $\delta 22.18, \delta 22.28$ and $\delta 22.89\left(\mathrm{t}, \mathrm{sp}^{2}, \mathrm{C}-1\right)$, two peaks of $\delta 24.66$ and $\delta 24.95$ and five peaks of $\delta 25.22, \delta 25.62, \delta 25.72, \delta 25.81$ and $\delta 25.93$ (d, sp,-CH-), one peak of $\delta 26.25 \mathrm{ppm}$, two peaks of $\delta 27.39$ and $\delta 27.79(\mathrm{~s},-\mathrm{C})$, two peaks of $\delta 28.17(\mathrm{t})$ and $\delta 28.44(\mathrm{t})$, six peaks of $\delta 29.30(\mathrm{t}), \delta 29.36(\mathrm{t}), \delta 29.47(\mathrm{t})$, $\delta 29.56(\mathrm{t}), \delta 29.66(\mathrm{t})$ and $\delta 29.90(\mathrm{t})$, one peak of $\delta 30.98(\mathrm{t})$ 
one peak of $\delta 31.72(\mathrm{t})$, two peaks of $\delta 32.12(\mathrm{t})$ and $\delta 32.93$ $(\mathrm{t})$, one peak of $\delta 34.15(\mathrm{t})$, one peak of $\delta 36.34(\mathrm{t})$, two peaks of $\delta 37.48(\mathrm{t})$ and $\delta 37.63(\mathrm{t})$, one peak of $\delta 39.56$, one peak of $\delta 43.01$, one peak of $\delta 62.30(q)$, one peak of $\delta 63.23(q)$, one peak of $\delta 76.81(\mathrm{~s})$, three peaks of $\delta 77.23(\mathrm{~s}), \delta 77.43(\mathrm{~s})$ and $\delta 77.65$ (s), two peaks of $\delta 127.30$ (d) and $\delta 127.94$ (d), one peak of $\delta 128.48$ (d), one peak of $\delta 130.41$ (d), one peak of $\delta 132.14(\mathrm{~s})$ and last peak of $\delta 178.69$ (s).

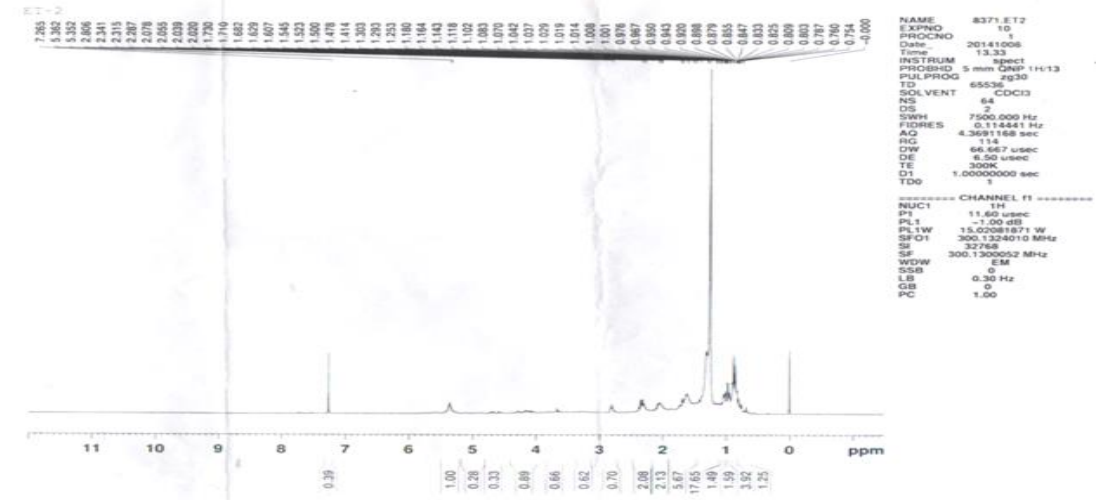

Figure 3: ${ }^{1} \mathrm{HNMR}$ spectra of purified fraction (ET-2)

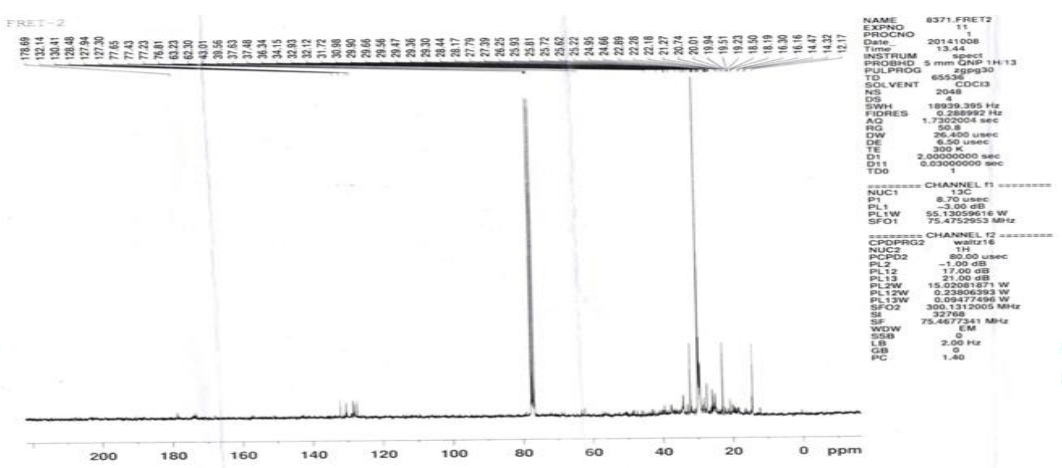

Figure 4: ${ }^{13}$ CNMR spectra of purified fraction (ET-2)

Mass spectrum of purified fraction of E. Thymifolia (ET-2) was analyzed for detection of biologically active compound on mass spectrometer and peaks were observed in the fig 5 . In ESIMS, first peak was reported at $118.0860(\mathrm{~m} / \mathrm{z})$ that confirms the presence of Phenyl Propene or Allyl Benzene or Indane with molecular formula $\mathrm{C}_{9} \mathrm{H}_{10}$ (Fig. 6A). A prominent spectral peak at $149.0232 \mathrm{~m} / \mathrm{z}$ confirms the presence of 2 hydroxy pentane-dioic acid with molecular formula $\mathrm{C}_{5} \mathrm{H}_{8} \mathrm{O}_{5}$ (Fig.6B). A largest peak reported at $391.2853 \mathrm{~m} / \mathrm{z}$ depicts the presence of Di-N-Octyl phthalate with molecular formula $\mathrm{C}_{24} \mathrm{H}_{38} \mathrm{O}_{4}$, (Fig.6C). A large peak at $279.1578 \mathrm{~m} / \mathrm{z}$ confirms the presence of 2-methoxyisoxazolidine-3, 3, 5, 5-tetra carboxylic acid with molecular formula $\mathrm{C}_{8} \mathrm{H}_{9} \mathrm{NO}_{10}$, (Fig.6D). A large peak reported at $441.3737 \mathrm{~m} / \mathrm{z}$ confirms the presence of $4 \alpha$-Carboxy $-4 \beta$-Methyl- $5 \alpha$-Cholesta-8, 24-dien$3 \beta$-ol with molecular formula $\mathrm{C}_{29} \mathrm{H}_{45} \mathrm{O}_{3}$. (Fig.6E). One of the peak reported at $593.2726 \mathrm{~m} / \mathrm{z}$ confirms the presence of 2 (5'-0-Methyl-3'- YL-)-N-[(S)-1-(2'- $\alpha$-Methoxy-3'- $\alpha$-Methyl-5'Deoxythymidine-5'-YL)Ethyl] Acetamide with molecular formula $\mathrm{C}_{27} \mathrm{H}_{39} \mathrm{~N}_{5} \mathrm{O}_{10}$. (Fig.6F). Rest of the peaks was also seen in the mass spectrum which was found due to fragmentation of terpenoidal compound present in the bioactive compound.

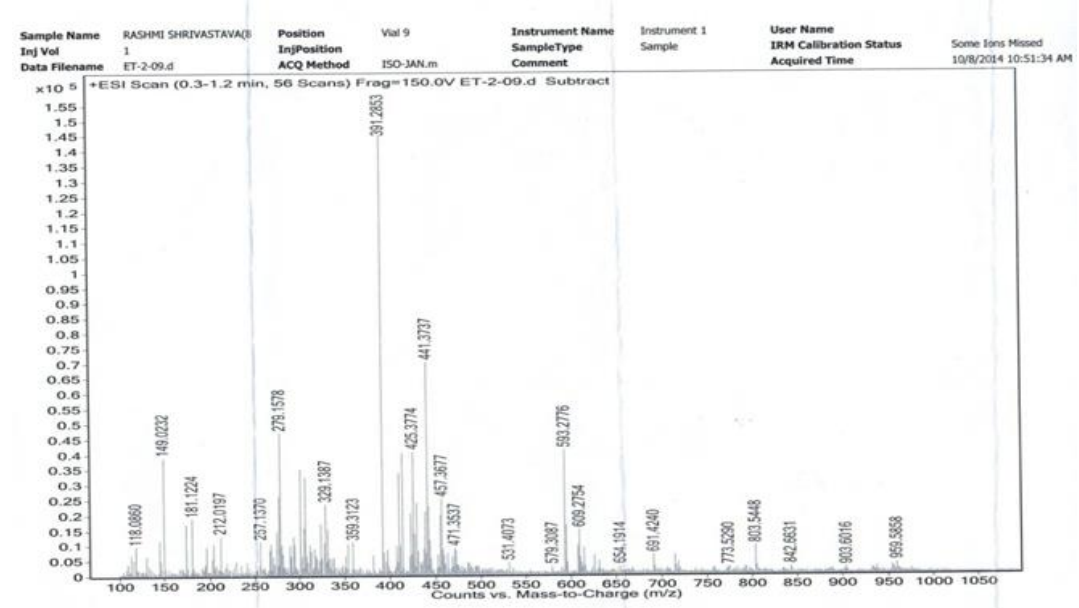

Figure 5: MASS Spectra of purified fraction (ET-2) 
<smiles>C/C=C\c1ccccc1</smiles>

(A)<smiles>O=C(O)CCC(O)C(=O)O</smiles>

(B)

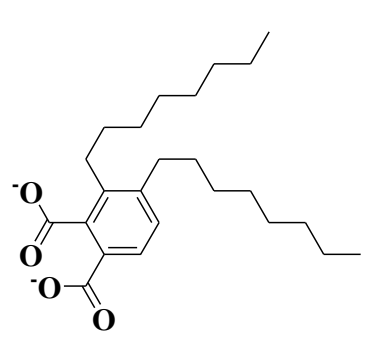

(C)<smiles>CC(C)=CCC[C@H](C)[C@H]1CC[C@H]2C3CCC4(C)[C@](C)(CC[C@H](O)[C@]4(C)C(=O)O)[C@H]3CC[C@]21C</smiles>

(D)<smiles>CC(C)=CCCC(C)C1CCC2C3=C(CC[C@]21C)[C@@]1(C)CC[C@H](O)[C@](C)(C(=O)O)[C@@]1(C)CC3</smiles>

(E)<smiles>CCn1cc(C)c(=O)[nH]c1=O</smiles><smiles>Cc1cn([C@H]2CC(CC(=O)N[C@H](C)C[C@H]3O[C@@H](O)[C@H](O)[C@@H]3O)C(CO)O2)c(=O)[nH]c1=O</smiles>

(F)

Figure 6: (A) Phenyl Propene (B) 2-Hydroxypentanedioic acid (C) Di-N-Octylphthalat (D) 2-methoxyisoxazolidine-3, 3, 5, 5-tetracarboxylic (E) 4alpha-Carboxy-4beta-methyl-5alpha-cholesta-8,24-dien-3beta-ol (F) 2-(5'- 0-Methyl-3'Deoxythymidin-3'-Yl)-N-[(S)-1(2'Alpha-Methoxy-3'-0-Methyl-5'-Deoxythymidin-5'-Yl) Ethyl]Acetamide

\section{CONCLUSION}

From the result obtained it can be concluded that the whole plant of $E$. Thymifolia has medicinal values since it contains more secondary metabolites. Bioactive compound (Total 6) were isolated and identified by column, thin layer chromatography and which were subjected to spectral analysis i.e. IR, UV, 1D NMR (1H-NMR and 13C-NMR) and mass spectroscopy from methanol extract of E. Thymifolia (ET-2) whole herb. These compounds have been reported for the first time in this plant and can serve as a useful tool in its standardization. Methanolic extracts shows good results regarding presence of phytoconstituents hence these plants may directly use in medicine preparation or for the development of novel agents for various pathological disorders. Further research on the health benefits of phytochemicals in this plant may be warranted.

\section{Conflict of interest}

The authors declare no conflict of interest.

\section{REFERENCES}

1. Ajithabai MD, Sunitha Rani SP, Jayakumar G. Review on the species of Sida used for the preparation of nayopayam kashayam. Int J Res Rev Pharm Appl Sci 2012; 2:173-95.

2. Visht $\mathrm{S}$, Chaturvedi S. Isolation of Natural Products. Curr Pharm Res 2012; 2(3):584-599.

3. Mishra GJ, Reddy MN, Rana JS. Isolation of Flavonoid Constituent from Launaea procumbens Roxb by Preparative HPTLC Method. IOSR J Pharma 2012; 2(4):5-11.

4. Samuelson G. Drugs of Natural Origin, A textbook of Pharmacognosy. 5th ed. Stockholm: Swedish Pharmaceutical Press. 2004.

5. Latanzio V. Phenolic Cpmpound : Introduction Springer-Verlag Berlin Heidelberg 2013; 1543-1579.

6. Derong L, Xiao M, Zhao J, Li Z, Xing B, et al. Review An Overview of Plant Phenolic Compounds and Their Importance in Human Nutrition and Management of Type 2 Diabetes. Molecules 2016; $21: 1374$.

7. Gadhvi R, Reddy MN, Gaurav JM. Isolation of terpenoids constituents from Lippia nodiflora by preparative HPTLC method. Int J Med Plants Alter Med 2013; 1(3):104-9.
8. Mitra R. Bibliography on Pharmacognosy of Medicinal Plants, National Botanical Research Institute, Lucknow, 1985; 239.

9. Siddiqui MB, Husain W. Traditional treatment of gonorrhoea through herbal drugs in the province of Central Uttar Pradesh, India. Fitoterapia 1993; 64(5):399-403.

10. Khan NH, Rahman M, Nur-e-Kamal MSA. Antibacterial activity of Euphorbia thymifolia Linn. Indian J Med Res 1988;87(6):395-7.

11. Banerjee DK, Pal DC. Plants used by the tribal of plain land in India for hair and scalp preparation, Fourth Int. Congr. Ethnobiol., NBRI, Lucknow 1994; 17(21):340.

12. Pal S, Gupta I. In vitro studies on the antifungal activity of Chotidudhi plant (Euphorbia prostrata Ait. and Euphorbia thymifolia Linn.). Indian J Pharmacol 1971; 3:29.

13. Jabbber A, Khan GMAS. Antimicrobial alkaloids from Euphorbia thymifolia. Pak J Sci Ind Res 1965; 8(I):293-4.

14. Singla AK, Pathak K. Anti-inflammatory studies on Euphorbia pmstrata. J Ethnopharmacol. 1989; 27(1):55-61.

15. Singla AK, Pathak K. Topical anti-inflammatory effects of Euphorbia prostrata on carrageenan induced foot pad oedema in mice. J Ethopharmacol 1990; 29(3):291-4.

16. Manickam K, Rajappan K. Inhibition of antiviral activity of certain leaf extracts against tomato spotted wilt virus in cowpea. Ann Plant Prot Sci 1988; 6(2):127-30.

17. Sharma GD, Tripathi SN, Sharma CD. Evaluation of a herbal drug "Dugdhika" (Euphorbia prostrata W. Ait. and E. thyrnifolia Linn.) for the treatment of bronchial asthma (Tarnaka shvasa). Asian Conf Trad Asian Med, Bombay, India. 1983; Abstr. No. C60.

18. Sharma GD, Tripathi SN. Experimental evaluation of Dugdhika (Euphorbia prostrata W. Ait) for the treatment of "Tarnaka Svasa' (Bronchial asthma). Ancient Sci Life 1983; 3(3):143-50.

19. Sharma GD, Upadhyay BN, Tripathi SN. A clinical trial of Euphorbia prostrata W. Ait and E. thyrnifolia Linn. in the treatment of bronchial asthma (Tarnaka shvasa). J Res Ayur Siddha 1982; 3(3-4):109-18.

20. Akhtar MS, Khan QM, Khaliq T. Effects of Euphorbia prostrata and Fumaria parviflora in normoglycaemic and alloxan-treated hyperglycaemic rabbits. Planta Medica 1984; 50(2):138-42.

21. Alarcon-Aguilara FJ, Roman-Ramos R, Perez-Gutierrez S, Aguilar-Contreras A, Contreras-Weber CC, Flores-Saenz JL. Study of the anti-hyperglycemic effect of plants used as antidiabetics. J Ethnopharmacol 1998; 61(2):101-10.

22. Handa SS, Chawla AS, Maninder. Hypoglycaemic plants-A review. Fitoterapia 1989; 60(3):195-224. 
23. Baslas RK, Agarwal R. Chemical investigation of some anticancer plants of Euphorbia genus. Indian J Chem 1980; 19B(8):717-8.

24. Sabu P, Saheed S, Ghouse AKM. Air pollution hazard on an indigenous drug plant Euphorbia thymifolia Linn. Medicinal Plants: New Vistas of Res. 1993; 11(2):549- 53.

25. Lin CC, Cheng HY, Yang CM, Lin TC. Antioxidant and antiviral activities of Euphorbia thymifolia L. J Biomed Sci 2002; 9(6):656-64

26. Makoto N. Flavonol glucoside from Euphorbia thyrnifolia L. J Agr Chem Soc Japan. 1941; 17:483-484. Chem Abstr, 1942, 3625.

27. Gupta DR, Garg SK. Chemical examination of Euphorbia thymifolia. Indian J Appl Chem 1966; 29(1):39-40.

28. Behari M, Gupta M. Chemical analysis of Euphorbia thymijiolia Linn., Proc. 67" Session, Indian Sci. Congr., Calcutta, Part I11 (Chemistry Section), Abstr. No. 214, 1980.

29. Agarwal R, Baslas RK. Chemical examination of the aerial parts of Euphorbia thymifolia. Indian J Pharm Sci 1981; 43(9):182-3.

30. Lee SH, Tanaka T, Nonaka G, Nishioka I. Hydrolysable tannins from Euphorbia thymifolia. Phytochemistry 1990; 29(11):3621-5.
31. Singla AK, Pathak K. Phytoconstituents of Euphorbia species. Fitoterapia 1990; 61(6):483-516.

32. Asolkar LV, Kakkar KK, Chakre OJ. Second Supplement to Glossary of Indian Medicinal Plants with Active Principles, Publications and Information Directorate, CSIR, New Delhi, Part I (A-K). 1992; 307.

33. Kokate CK Practical Pharmacognosy, $3^{\text {rd }}$ Edition, Vallabh Prakashan, New Delhi, 1991; 101-111.

34. Harborne JB. Phytochemical Methods, a guide to modern techniques of plant analysis, Chapman \& Hall, London, 1973; 3:182-189.

35. Trease GE, Evans WC. Pharmacognosy. 12 $12^{\text {th }}$ Edition, ELBS Publications, London, 1985, 126-137.

36. Brady LR, Robber JE. Pharmacognosy 9th edition, Lea and Febiger Publication, Philadelphia, 1988: 77-79.

37. Peach K, Tracy MV. Modern Methods of Plant analysis, Vol.3\&4, Springer-Verlag, Heidelberg. 1955; 3-4.

38. Brimley RC, Barrette FC. Practical Chromatography. Chapman and Hall Publication, London. 1953; 26.

39. Rao CNR. Ultraviolet and Visible spectroscopy. 1975

40. Silverstein RM, Webster FX, Kiemle DJ. Spectrometric Identification of organic compounds. $6^{\text {th }}$ Edition. 1997. 